\title{
雨水利用の管理型ビオトープ
}

\author{
神谷 博

\section{Study of Biotope Controlled by Rainwater Circulation System}

\author{
Hiroshi Kamiya
}

Keywords: Biotope; Rrainwater use; Water circulation; Natural energy; Maintenance

\section{1 はじめに}

近年ビオトープづくりが全国的なブームとなっている. その多くは川や湖沼, 田, 里山など既にある自然若し くは半自然の環境に手を加えて自然度を高める試みで ある.ビオトープの単位のとり方は，大きな自然から ベランダビオトープのようなミクロなものまで様々で, 設置される場所も農山村域から都市域まで広がってい る. 本稿では都市域の建築的なスケールで人工的につ くられた水路や池のビオトープを取り上げている。建 築に付随して維持管理されるシステムであり，これを 「管理型ビオトープ」と呼ぶことにする。こうしたタ イプのビオトープも実施例が増えてきているが，その 考え方, システムは様々であり, 確立した方法がある わけではない，もともと多様性の高い環境をつくるこ とが求められるシステムであり, 評価も難しいが, 成 功例ばかりともいえないのが現状である. 本研究では, 人工的システムの中でも主に雨水を水源にし，自然工 ネルギーを用いた循環管理システムについて，その評 価方法の検討を行った.

\section{2 対象とした事例}

雨水利用の管理型ビオトープとして，これまでに自ら 手がけた事例を用いた。これらは自然エネルギーによ る雨水循環システムをほぼ同じ手法で用いている. 事例 1 : ルミナス武藏小金井 (東京都・小金井市) 事例 2 : 聖フランシスコ子供寮（東京都・大田区） 事例 3 : 幕張かるがも館（千葉県・船橋市/解体済） 事例 4 : 洗足学園小学校（神奈川県・川崎市） これらの概要については表 1 のとおりである.

\section{1 システムの概況}

何をもってシステムを評価するかは，状況によって異 なるが，ここでは自然度を高めることと，維持管理を たやすくすることのバランスという視点を据え, 評価 に関わる概況を整理した.

・管理上，手間やコストの問題を生じていないか

・ビオトープとして生物の生息環境が成り立っている か

・居住者に受け入れられ，喜ばれているか

これらはクリアすべき基本的な要件であるが，取り上

法政大学工学部兼任講師, Assistant Professor, Faculty of Engineering, Hosei University, 3-7-2 Kajino, Koganei, Tokyo 184-8584 Japan
げた事例で見られた状況は以下のとおりである.

\subsection{1 管理上の問題}

・どのケースでも夏場にアオミドロが大量に発生す る：一時期のものであり人力による除去を指導, 実 施している.

・冬場に水不足になりがちとなる：事例 1 では緑化用 の雨水槽との水量配分を変更して対応した。

- 風車の維持管理 : 事例 1 については設置方法の問題 から水落ちが起きやすい. 事例 3 についてはシャフ トの摩擦音が生じたことがあった。これらには定期 的なメンテナンス (年 1〜2 回) で対応している. 事 例 3 は仮設で, 風車のみのシステムとしたが水量・ 水質ともに他事例より問題が起きや寸かった。

\subsection{2 ビオトープとしての環境}

・導入種 : 最初に実施した事例 1 では, 由緒の分かっ ているクロメダカを放流したが，その後自生してメ ダカ〜ユスリカの安定した生態系となっている. 事 例 2 は事例 1 からクロメダカを移し, 事例 4 では事 例 2 からさらに移してそれぞれに自生し, 環境に適 応している.

- 生態的環境 : 事例 3 は仮設のため金魚のみを放し, 水路も自然度を抑える方法をとったが，生態系とし ての安定度に欠け，かえって維持管理に手間がかか った.

\subsection{3 居住者の満足度}

-事例 1 では事前と完成後のアンケート調査を行なっ ている. 当初事業者が最も心配したものがビオトー プだったが結果は逆に満足度の高いものとなった.

・他の事例でも, 若干の管理上の問題はあるが居住者 の満足が損なわれる状況ではない. 事例 3 は居住者 ではないが来館者と子供に好評であった。

各事例については以上のような状況にあるが，自然 エネルギーを用いたシステムとしてこれまで概ね成り 立ってきた. その要因の一つである循環システムがど のように稼動してきたかは大事なポイントであり，こ れを検証することとした。

2.2 循環システムの位置づけ

人工的につくられる水系のビオトープシステムは，そ 
表 1: 雨水ビオトープ事例比較表

\begin{tabular}{|c|c|c|c|c|}
\hline & 事例 1 & 事例 2 & 事例 3 & 事例 4 \\
\hline \multirow[t]{3}{*}{ 水面形態 } & 水路型 & 水路十池型 & 池十水路型 & 池型 \\
\hline & \multirow{2}{*}{$\begin{array}{l}\text { 幅 } 0.6 \sim 1.2 \mathrm{~m} \\
\text { 長 } 60 \mathrm{~m}\end{array}$} & 幅 $0.6 \mathrm{~m}$, 長 $10 \mathrm{~m}$ & \multirow{2}{*}{$\begin{array}{l}\text { 幅 } 0.6 \mathrm{~m} \sim 1.2 \mathrm{~m} \\
\text { 長 } 20 \mathrm{~m}\end{array}$} & 幅 2〜3m, 長 $10 \mathrm{~m}$ \\
\hline & & 幅 $3 \mathrm{~m}$, 長 $10 \mathrm{~m}$ & & 幅 $3 \mathrm{~m}$, 長 $8 \mathrm{~m}$ \\
\hline \multirow[t]{2}{*}{ 水深 } & \multirow[t]{2}{*}{$15 \mathrm{~cm}$} & $10 \sim 15 \mathrm{~cm}$ & \multirow[t]{2}{*}{$15 \sim 30 \mathrm{~cm}$} & $15 \sim 50 \mathrm{~cm}$ \\
\hline & & $10 \mathrm{~cm}$ & & $10 \mathrm{~cm}$ \\
\hline \multirow[t]{3}{*}{ 貯留槽 } & $\mathrm{RC}$ 造 & プラスチック製 & プラスチック製 & プラスチック製 \\
\hline & 地下型 & 地下型＋地上型併用 & 地下型 & 地下型 \\
\hline & $35 \mathrm{~m}^{3}$, 緑用 $70 \mathrm{~m}^{3}$ & $30 \mathrm{~m}^{3}$ & $10 \mathrm{~m}^{3}$ & $29 \mathrm{~m}^{3}$ \\
\hline 集水域 & $\begin{array}{l}\text { 屋根 } \\
\text { 約 } 650 \mathrm{~m}^{2}\end{array}$ & $\begin{array}{l}\text { 屋根及び地表 } \\
\text { 約 } 200 \mathrm{~m}^{2}\end{array}$ & $\begin{array}{l}\text { 屋根及び地表 } \\
\text { 約 } 100 \mathrm{~m}^{2}\end{array}$ & $\begin{array}{l}\text { 屋根 } \\
\text { 約 } 400 \mathrm{~m}^{2}\end{array}$ \\
\hline 循環システム & $\begin{array}{l}\text { 揚水風車+ソーラー発 } \\
\text { 電によるポンプ } \\
\end{array}$ & $\begin{array}{l}\text { 揚水風車+ソーラー発 } \\
\text { 電によるポンプ } \\
\end{array}$ & 揚水風車 & $\begin{array}{l}\text { 揚水風車+ソーラー発 } \\
\text { 電によるポンプ } \\
\end{array}$ \\
\hline 導入種 & クロメダカ & クロメダカ & （金魚） & クロメダカ \\
\hline $\begin{array}{l}\text { ビオトープ以外 } \\
\text { 雨水の用途 }\end{array}$ & $\begin{array}{l}\text { 屋上菜園, 屋上緑化, 壁 } \\
\text { 面緑化 }\end{array}$ & 庭木への散水 & 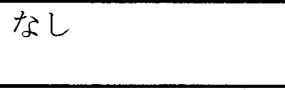 & なし \\
\hline 建物用途 & 分譲集合住宅 & 子供養育施設 & 住宅案内所（仮設） & 教育施設 \\
\hline
\end{tabular}

表 2: ビオトープシステム比較表

\begin{tabular}{l|l|l|l}
\hline & \multicolumn{1}{|c|}{ 場所 } & \multicolumn{1}{|c}{ 水源 } & \multicolumn{1}{|c}{ 循環システム } \\
\hline 自然系ビオトープ & 川, 湧水, 湖沼 & 川, 湧水, 湖沼 & 自然のまま \\
\hline 人工系ビオトープ (機械管理) & 公園, 建築 & 水道, 井戸水, 雨水 & 機械循環設備 \\
\hline 人工系ビオトープ (自然エネルギ一管理) & 建築, 公園等 (今後) & 雨水 & 風車, 太陽電池など \\
\hline
\end{tabular}

の水源の確保が課題の一つとなる. 水道水や井戸水を 用いる場合は水量の安定確保が容易であり，コストを いとわなければ給水のみのシステムも可能である。し かし，雨水を主に用いる場合には，その貯留施設と循 環システムが必要となる。一方, 自然系のビオトープ は，現存する自然に手を加えて自然度を高めるだけで あり，新たなエネルギーも循環システムも必要としな い放置型のシステムである.人工の循環システムは, これまで水道や電力などオフサイトのエネルギーに頼 るケースが多かったが，これに対して，オンサイトの 自然エネルギーを用いた管理型ビオトープは半放置型 システムであり，自然系ビオトープとの中間に位置づ けられる。表 2 に各ビオトープの比較を示す.

\section{3 自然エネルギーによる循環システム}

事例では循環システムに風車と太陽電池による自然エ ネルギーを用いており，これまでのところビオトープ との適合性がよいと思われる結果を得ている。 その理 由として, 機械的運転でなく, 自然のリズムに対応し て稼動するために多様性の高い環境を得ているためで はないかと考えられる。ここで用いているシステムは 次のとおりである.

(1) 揚水風車

・ドイツ製の灌溉用揚水風車，汲み上げ揚程約 $22 \mathrm{~m}$, 強風対策装置付, ダイヤフラムポンプ最大揚水量 300 $\ell /$ 分

・弱風でも羽根が回れば水が出るので効率はよい，風 は常時吹かないものの昼夜を問わず稼動する．大風 時には大水を汲み上げるが，常時も風のリズムに従 って水量が変動する.

\section{(2) ソーラーポンプ}

・太陽電池 50〜 55w のパネル 1 枚で， 50w の直流ポン プを稼動させる．蓄電はせずに太陽光の強さによっ て変化する発電量に応じてポンプが稼動する.

・ ポンプの吐出量は風車より小さく, 最大 $10 \ell /$ 分程 度だが，尽間は安定して稼動する。

この二つの異なる特性をもつポンプを単に並列に用 い連動させない，これによって，むらのあるそれぞれ の自然エネルギーをカバーしあうシステムとしている. 水環境としては, 止水域と流水域の両方の性格を持ち, メダカの生息には適している。 大風時に風車によって つくられるフラッシュ流は, 自然の川の洪水と同様に 水質面で大掃除の役割を果たす。

\section{1 システムの評価方法}

循環システムの評価方法として「循環回数」と「循環 平準度」を求めて検討することとした。本稿では主に

「循環回数」についての検討を行ったが, 今後, 評価 軸を増やした上でビオトープ及び建築を単位とした雨 水の「循環能」として指標化することをめざしたい.

\subsection{1 循環回数}

循環回数は, ビオトープ部分に存在する水が入れ替わ る回数（開水部循環回数 $\mathrm{n}_{\mathrm{o}}$ ) と, 貯留部分に存在する 水が入れ替わる回数 (貯留部循環回数 $\mathrm{n}_{\mathrm{i}}$ ) とに分けて 検討を行なった. 雨水による給水のない貯留時におい ては， $\mathrm{n}_{\mathrm{o}}$ は一般的に多い方がよく， $\mathrm{n}_{\mathrm{i}}$ は少ない方がバ ックアップ能力が高い. これを合わせた評価として, 循環比を求め, 循環能力の指標とする. 通常設計に際 して開水部と貯留部の容積比を目安として，これを極 
力大きくしようとする．循環比はこれに対してもう一 つの尺度となり，循環比が大きければ水質維持も含め た総合的な循環能力が高いと判断できる. 算出式は次 のとおりとする.

開水部循環回数 $=$ 開水部給水量/開水部容量 貯留部循環回数=貯留部流入量/貯留部容量 循環比=開水部循環回数/貯留部循環回数 ここに,

開水部給水量=風車揚水量+ソーラポンプ揚水量 貯留部流入量 $=$ 開水部給水量·蒸発散量 $(=0.7)$

\section{2 循環回数によるシステムの検証，評価}

\subsection{1 風車揚水量の想定}

風力については, 地域ごとの条件によって差が大きく， 風車の性能も微気候に大きく左右される。従って個別 に詳細な風力データを得ることは難しい．ここでは， 気象庁アメダスによる府中市の月平均風速を用い，事 例 3 のみは海岸近くであるため, 2.0 倍の補正を行なつ た。また，揚水風車のエネルギ一効率を旧来の多翼型 風車の一般的な効率である $30 \%$ に対して $40 \%$ とした。

(風車揚水量) $=$ (風速当たり揚水量 $) \times$ (平均風速) $\times$ (地域補正率) $\times 0.4$ (効率)

\subsection{2 ソーラーポンプ揚水量の想定}

太陽光発電の発電量については NEDO（新エネルギ 一・産業技術総合開発機構）や各メーカーから細かい 数值が示されており，通常は日射量との関係で示され る. 日射量と発電量, ポンプの揚水量との関係は単純 ではなく，個別条件によっても大きく左右される。し かし，発電量はポンプの能力に合わせて設計されてい るため,ここではポンプの能力を主として算定した。 ポンプの形式は小型のダイヤフラムポンプで $12 \mathrm{~V} タ イ$ プと $24 \mathrm{~V}$ タイプを用いている. 能力は 3 事例とも異な っており，それぞれの性能数值を用いた，尚，日射量 はNEDO の資料を用い, 発電効率の補正に総合設計係 数（K 值）の一般值 0.7 を用いた.

(ソーラーポンプ揚水量) $=$ (発電量当たり揚水量)

$\times$ (パネル当たり発電量) $\times 0.7$ (総合設計係数)

図 1〜4に，風車揚水量，ソーラーポンプ揚水量に ついて示す。これらから，このシステムの場合には風 車の稼働能力がソーラーより大きい事がわかる．事例 3 では海岸近くで風を期待できる場所であったためソ 一ラーを用いていないが，組合わせシステムより大き い值となっている。また，風車揚水量は季節により変 動が大きく，ソーラーポンプ揚水量は比較的安定して いる事がわかる，従って，合成された揚水量も風車に よる変動パターンをトレースしたものとなっている.

\subsection{3 循環回数の算定}

風車とソーラーポンプによる揚水量は連動したシステ ムではなく，それぞれに独立している．従ってこれを 単純に加算することで合成された揚水量となる。これ により各事例ごとの循環回数及び循環比を求めた。図 5〜8に結果を示す.

循環回数は，事例 2 のみ他に比べて際立った値とな っているが，ここではビオトープ以外の雑用水への利 用を含んでいるために貯留容量が開水部容量に比べて 大きくなっている．循環比では事例 3 が他に比べて低

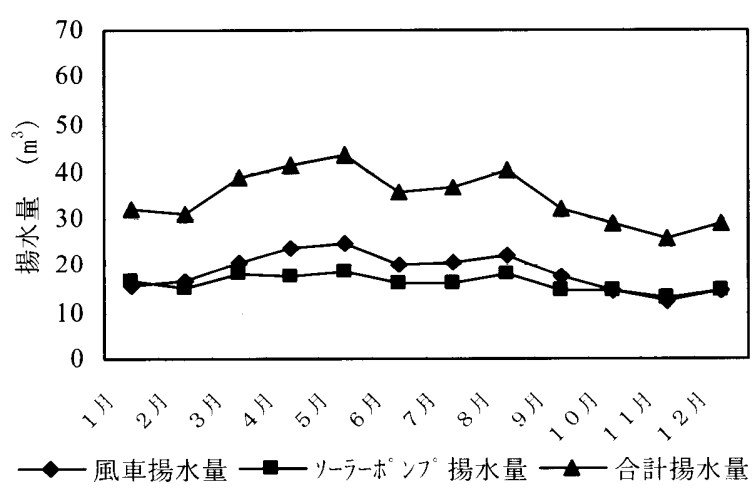

図 1: 事例 1 ルミナス武蔵小金井

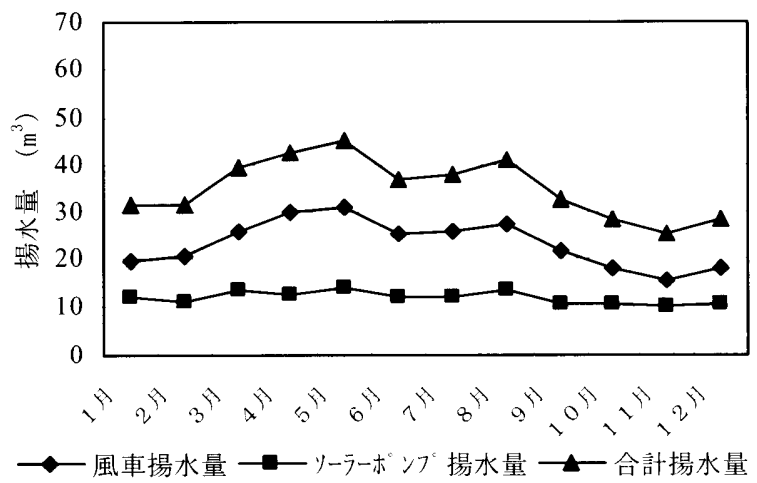

困 2: 事例 2 聖フランシスコ子供寮

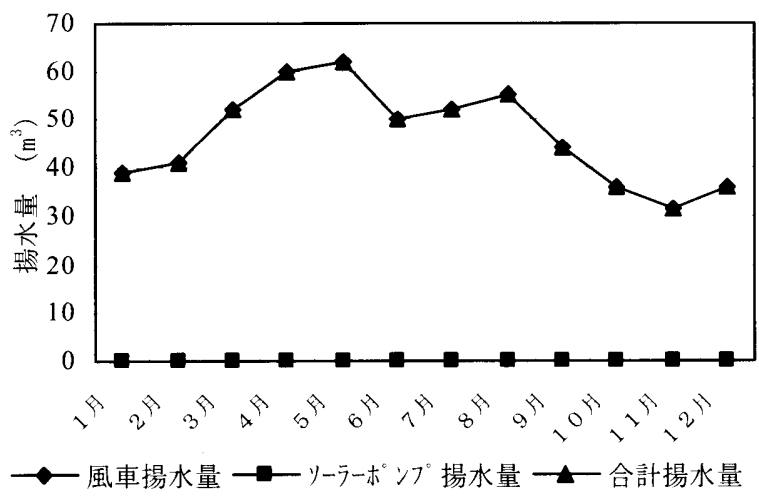

図 3: 事例 3 幕張かるがも館

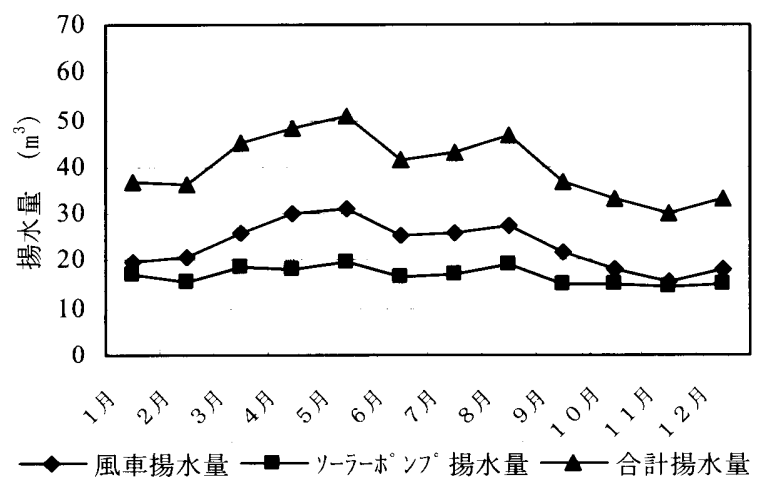

図 4: 事例 4 洗足学園

くなっているが, システムの運転時に管理上やや問題 


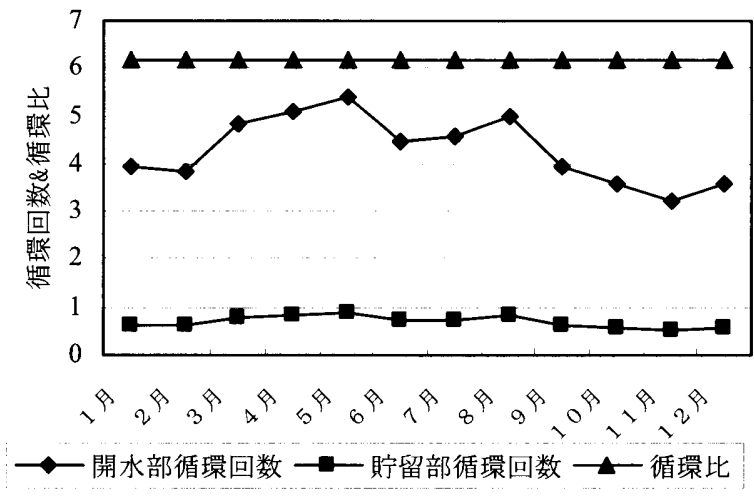

図 5: 事例 1 ルミナス武蔵小金井

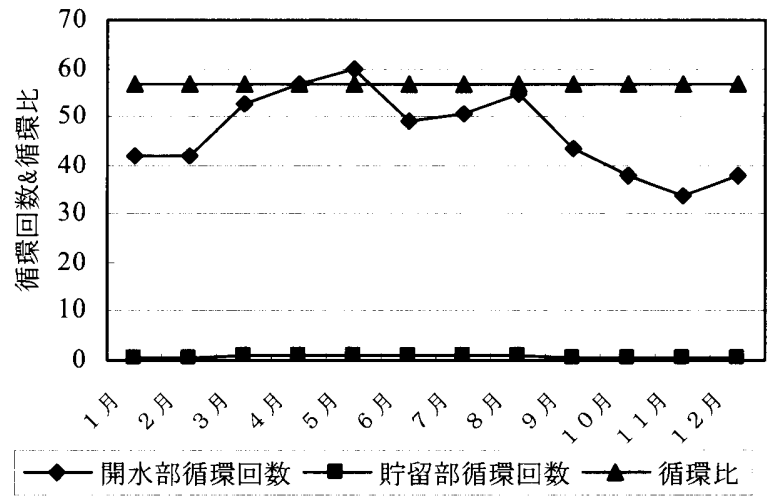

図 6: 事例 2:聖フランシスコ子供寮

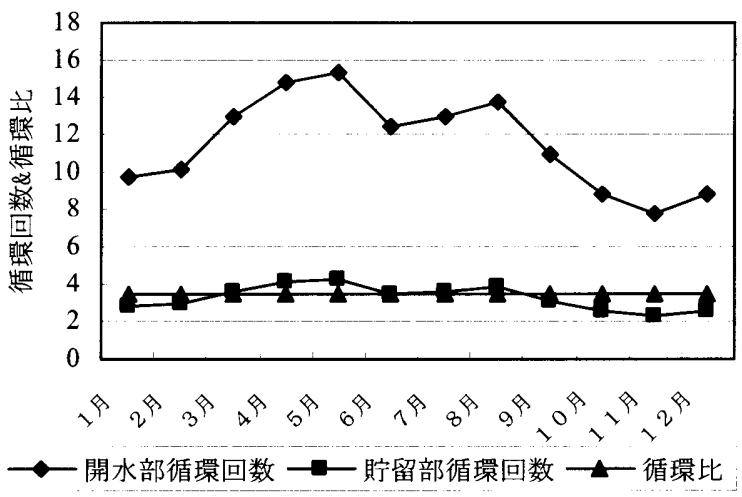

図 7: 事例 3 幕張かるがも館

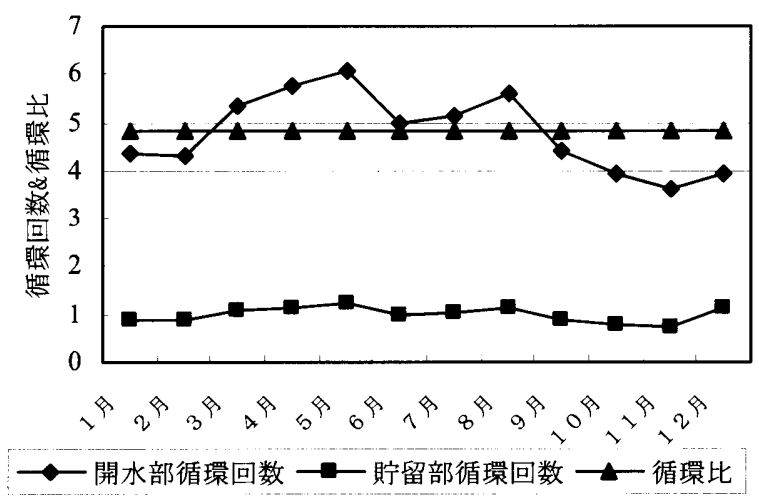

図 8: 事例 4 洗足学園

があったこととの関連性が伺われる．また事例 1 と 4

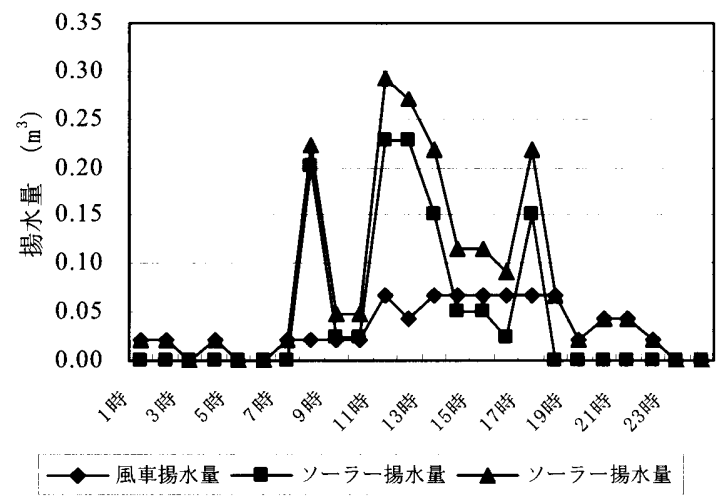

図 9: 循環平準度(2001 年 8 月 14 日府中市)

は似通った性格のシステムを持っていることが分かる.

\section{2 .4 循環平準度}

循環平準度は, 風車とソーラーポンプによって合成さ れる循環のリズムを示すものとする。自然のリズムは 長期に均せば規則的であるが，短期的には不規則なリ ズムを持っている．利用面からすると問題のあるムラ となるが，これが生態的な多様性をもたらす大事な要 素でもあり，適度に平準化されることが望ましい，

循環システムで実質的に問題になるのは, 月レベル の平均值より毎日のリズムであり，これは季節によっ ても異なるパターンとなる。. 日パターンごとの検討は 今後の課題とし，ここでは一例として，2001 年 8 月 14 日府中市における夏期の状況を図 9 に示す。 1 日 24 時間の中では，ソーラーポンプが昼間しか運転しない ため, 循環パターンに偏りが出る. 風車との合成によ ってこれが均されると考えられるが 1 日単位では風の ばらつきも大きい，晴天日で見ると，ソーラ一の働き が大きいことがわかる，それでも風車が最低流量の底 上げに寄与していることが読み取れる。この例から見 ても，日パターンはかなりばらつきがあるため，循環 平準度については今後検討すべき点が多くある。

風車とソーラーポンプを組合せることでどのように 平準化されるのか，事例に当てはめて今後の検討を行 ないたい

\section{4 まとめ}

ここまで, 雨水循環システムの評価方法について検討 してきたが, 現実の運転状況をどの程度正確に反映で きているかは不明である.実測が容易ではないことや， アメダスの代表地点データと各現場との差も大きい. 想定した諸元についても今後検討の余地がある.

雨水ビオトープの技術的評価には, 循環システムの ほかにいくつかの評価軸が必要と考えられる.

- 雨水の集水, 給水面の性能

- 貯留槽の構造, 取水装置の性能

・開水部の底質の容量及び材質

- 水生の植物や生物の浄化能力，水質負荷・基隻 等, この他にコスト，管理，居住者の評価等，ソフト の評価軸を合わせて総合的な評価となる．設計に際し てはこれらについて何らかの指標が得られれば分かり や寸い，循環回数，循環比はその意味で手がかりの一 つとなり得ると思う. 本稿を手がかりに，他のタイプ のシステムとも比較することで今後の指標化につなげ てゆきたい. 